\title{
AN ECOCRITICAL APPROACH TO AMITAV GHOSH'S THE HUNGRY TIDE
}

\author{
Maharajan, S. \\ Department of English, V.H.N.S.N. College (Autonomous), Virudhunagar.
}

\section{ABSTRACT}

The aim of this paper to Projects the impact of ecology in literature Ecocriticism is the interdisciplinary area which includes the study literature and environment. The literary scholar analyzes the text not only for the environmental concerns but also to the treatment of ecology as the subject of nature in literature. The word ecocriticism may have been first used William Rueckart's essay which entitled "Literature and Ecology: An Experiment in Ecocriticism". The Hungry Tides tells the very present story of the present day adventure, identity, history and love. Ghosh here presents the nature not as the setting of picturesque beauty alone it also aprosis as hungry of human blood. The tide and its surages stand for all the devastating the aspects of nature.

Amitav Ghosh's The Hungry Tide set in the Sunder bans, is a sage of Indo-American marine biologist Piya Roy. She has been to the Tide country of sunder bans in Bengal with a view to studying river dolphins. Two characters Fokir, a local fisherman who helps her to locate dolphins in Garijiontda pool and Kanai Dutta, a Delhi- based business man who meets her on his way to visit his aunt Nilima come closer to Priya's heart in course at time. Nirma's human Nirmal once had a mission for helping the displaced refugee who settled on the sunder bans island of Morichjhapi. He has this commitment to work for and help the refugee as he falls in love with a refugee, Kusum, mother of inbant Fokir. The novelist inborns that Kanai visits the 'tide country' together the lost journal written by his dead uncle Nirmal. The journal is an account of the lives of the Morichjhapi Island which is later ruthlessly evicted by military troops which claims the life of Kusum. A sudden cyclone kills Fokir when he is assisting Piya on a journey on waterways. Finally Piya determines to establish a research trust in memory of Fokir and seeks help from Nilima and Kanai to translate her dream into reality.

Keywords: Adventure, Love, Identity and Symbols.

'An Eco Critical Approach to Amitav Ghosh's The Hungry Tide'

Ecocriticism is an intentionally broad approach that is known by a number of other designations, including "green (cultural) studies" "ecopoetics" and "environmental literary criticism" and is often informed by other fields such as ecology, sustainable design, biopolitics, environmental history, environmentalism, and social ecology, among others.

The novel The Hungry Tide is a masterfully conceived and admirable one. Its is highly different from other novel by Amitav Ghosh in its form. It consists of two parts, one is the Ebb: Bhata and part two is the Flood: Jowar. In part one the Ebb: Bhata consist of many chapters, titled under different names with different ideas. The title are not easily handled by Amitav Ghosh, they are the Tide country, an Invitation, Canning, the Launch, Lusibari, the Fall, S'Daniel, Snell's Window, the Trust, Fokir, the Letter, the Boat, Nirmal and Nilima, at Anchor, Kusum, Words, the Glory of Bon Bibi, Stirrings, Morichjhapi, an Epiphany, Moyna, Crabs, Travels, Garjontola, a Disturbance, Listening, Blown Ashore, a Hunt, Dreams, and Pursued. In part two the Flood: Jowar consist of many titles they are Beginning Again, Land full, a Feast, Catching UP, Storms, Negotiation, Habits, a Sunset, Transformation, a Pilgrimage, Destiny, the Megha, Memory, Intermediates, Besieged, Words, Crimes, Leaving Lusibari, an Interruption, Alive, a Post Office on Sunday, a Killing, Interrogations, $\mathrm{Mr}$ Sloane, Kratie, Signs, Lights, a Search, Casualties, a Gift, Fresh Water and Salt, Horizons, Losses, Going Ashore, the Wave, the Day After, and Home: An Epilogue. Those titles which are mentioned above are entitled with names of character in the novel. The Hungry Tide tells a very no contemporary story of adventure and unlikely love, identity and history, set in one of the most fascinating regions on the earth.

Ghosh, in The Hungry Tide constructs nature by using interweaving legends, experience, myths and history to reveal human interaction with the non-human world. It also makes an attempt to find out his conscious engagement with the natural world that draws our attention to impending calamity of 
the global environment. Eco-critical approaches make inquiries into the connections between nature and human culture and it also views at what instant the authors represent its effects. The whole of the ecosphere where energy, matter and ideas come to an interaction is the basis of eco-criticism not alone the social world. Nevertheless, the fictional works of Indian writer in English, Amitav Ghosh, can be viewed through eco-critical perspective.

The novel tells a very present day story of adventure, identity and history and love. Ghosh here presents nature not as a setting of picturesque beauty alone it also appears as hungry of human blood. The tide and its surges stand for all the devastating aspects of nature. We may spot the following expression about mangrove forest from the Bengali script that Kanai reads in the novel:

"A mangrove forest is a universe into itself...Mangrove leaves are tough and leathery, the branches gnarled and the foliage often impassable dense. Visibility is short and the air still and fetid. At no moments can human beings have any doubt of the terrain's utter hostility to their presence, of its cunning and resourcefulness, of its determination to destroy and expel them. Every year dozens of people perish in the embrace of that dense foliage, killed by tigers, snakes and crocodiles."

The above quoted passage unfolds the tremendously unreceptive approach of nature towards man. Ghosh has presented, in the section entitled "S" Daniel", a discussion between Nirmal and Kanai about "S" Daniel's efforts in bringing people to the tidal region, which was weighed down with numberless hazards and risks to their lives. It is a matter of pity that the tidal surroundings bring not only the sudden danger to the inhabitants but a constant fear-psychosis:

"Think of what it was like: think of the tigers, crocodiles and snakes that lived in the creeks and nalas that covered the islands. This was a feast for them. They killed hundreds of people." (Ibid 52)

The work is purely of both natural and human environment. The Tide country i.e Sunderbans to which the whole of the work is devoted is not only a far-flung land of intimidating physical environment but also a place of dealings among an assortment of communities-ethnic, religious, linguistic, cultural etc.

The novelist meticulously offers the nexus: the man-nature complex interactions. Like manifest threats posed by human settlement to the unique diversity of aquatic and terrestrial life in the mangrove swamps and the constant depletion of aquatic species by fishing and trawling, the human settlers too fall victim to constant erosion of dykes and embankments, the silting up of channels, the flooding by storm waters.

The author's nuanced descriptions of the moods and microenvironments of the island serve a lush backdrop for an intricate narrative that moves fluidly between past and present. The climatic ending, in which a cyclone threatens the inhabitants of the Sunderbans, underscores Nirmal's observation that "nothing escapes the maw of the tides." (Ibid 225)

Ghosh accurately orchestrates the marvelstigers, river dolphins, crocodiles, lunar rainbows and the tides-which go against the settlers. The work is an ineradicable mark bearing a conflict between wilderness and human civilization.

The Hungry Tide is not only a work of fiction with a well-knitted story but also it is rich in its symbolical implications. While treating an endangered ecosystem in the Bay of Bengal as its setting, Ghosh pinpoints various significant things through a number of nature symbols. Even the title of the work cannot be ignored as going simply as a title since it indicates several coats of meaning. The whole of the tidal region is represented as a place where ferocious animals pursue the human beings day and night. Besides, the frequent and sudden rise in tides brings danger to its inhabitants. Hence, the title immediately leads readers to an understanding of a situation where humans share with animals as tides bear all the devastating aspects of nature.

In the novel, the incident regarding Piya's fall in the sea indicates an aesthetic experience. The expression like "the muddy brown water was rushing up to meet her face" evokes in the reader's heart the Bibhatsa rasa or the rasa of indignation. Here it must be stated that rasa for the reader is the aesthetic experience in literature. A genuine reader experiences this aesthetic feeling, when he reads truly imaginative pieces of literature. This expression or the like in the novel turns up the whole situation to an epic feeling.

The tidal surges that get rhythmic in flow with the thematic concerns of the writer seem to be suggestive of the hard-hitting human relationship in the novel. Piya's emotional attachment for Fokir and the envy of Kanai for the fisherman are patent in the following conversation between Piya and Kanai: 
'...Very few people can adapt themselves to that kind of rhythm-one in a million, I'd say. That is why it was so amazing to come across someone lie Fokir.'

\section{'Amazing? Why?'}

'You saw how he spotted that dolphin there, didn't you? ', said Piya. 'It's like he's always watching the water-even without being aware of it. I have worked with many experienced fishermen before but I've never met anyone with such an incredible instinct: it's as if he can see right into the river's heart

The noisy rise in tides, the dreadful movements of the tigers, the picture of the all encircling mud in the expressions like 'a shroud closing in on her' and 'folding her in its cloudy wrappings' along with its comparison with 'the slippery walls of a placental sac' are some of the evidences emblematic implications in the novel. The silent passion prevailing between Piya and Fokir appears as a symbolic indication of the tension between the-environmental position of the Sunderbans and the needs of the human beings who seek to survive in that hostile environment.

In "The Hungry Tide", the story is based on an eco-setting, an immense archipelago of islands, Sunderbans. The cyclone has snapped the fragile balance between man and nature in the delicate ecosystem of the islands. The following shimmering expression in the novel captures the very tone of this environment

"At low tide, when the embankment was riding high on the water, Lusibari (island) located like some gigantic earthen ark, floating serenely above its surroundings. Only at high tide was it evident that the interior of the island lay well below the level of the water. At such times the unsinkable ship of a few hours before took on the appearances of a flimsy saucer that could tip over at any moment."

The novelist has the absolute ingenuity to keep analogy between the imaginative pictures of the tide country situation with the ecosystem. It is really true that this dichotomy, wild life versus human suffering or destruction of the ecosystem versus human survival could not have been put in better words than Ghosh. The following passage proves:

The settlers of the Sundersbans believe that anyone who dares venture into the vast water labyrinth without a pure heart will never return. It is the arrival of Piyali Roy of Indian parentage but stubbornly American, and Kanai Dutta, a sophisticated Delhi Business man, that disturbs the delicate balance of the settlement life and sets in motion a fateful cataclysm. Kanai has come to visit his widowed aunt and to review some writings left behind her husband, a political radical who died mysteriously in the aftermath of a local uprising. He meets Piya on the train from Calcutta and learns she has come to the Sunderbans in search of a rare species of river dolphin. When he hires Fokir, an illiterate, yet proud local fisherman to guide her through the mazelike backwaters, Kanai becomes her translator.

The novel Summoning a singular place from history he brings its myth and gives a life to it by making chronicles the saga of just such a group of refugees who were sent by the West Bengal government to Dandakaranya in Madhya Pradesh in 1961 but they left the place and returned to West Bengal in 1978 only to be massacred and evicted again. Ghosh's writing has never had a strict demarcation between fiction and non-fiction. He has always combined roles -that of novelist, journalist, scholar and historian. This novel arrests the novel intertwining accounts of the Morisjhapi Massacre of 1979 in the Sunderbans and the history of river dolphins which are an integral part of history and ecology. Ghosh dramatizes the last phase of the refugee struggle in the Sunderbans.

In the novel, the Morichjhapi Massacre is traced through a witness, Nirmal, and his diary to his nephew (Kanai). we come to know the facts of the incident from Nirmal's widow. Nilima runs a hospital and a trust in Lucibari and is known as "Mashima" (or aunt) to all. She tells her nephew Kanai of the events leading up to the massacre and of her husband's involvement in it:

"In this place where there had been no inhabitants before there were now thousands, almost overnight. Within a matter of weeks they had cleared the mangroves, built badhs and put up huts. It happened so quickly that in the beginning no one even knows who these people were. But in time it came to be learnt that they were refugees, originally from Bangladesh. Some had to come to India after partition, while others had trickled over later. In Bangladesh, they had been among the poorest of rural people, oppressed and exploited both by Muslim communalists and by Hindus of the upper castes"

Ghosh eloquently summarizes the events at Morichjhapi in 1979 through Nilima's narrative. His fictional representation of the event keeps very close 
to what actually happened, and he has successfully shown the various ways in which Morichjhapi was markedly different from other refugee settlements. The refugees there were displaced people-they had moved from East Pakistan to West Bengal, from west Bengal to Madhya Pradesh and then again from Madhya Pradesh to the Sunderbans. Yet, in Morichjhapi they had found a place where they no longer at the mercy of the local people or even the government, initially. They found vast tracks of free land in the Sunderbans and created a world of their own. However, the refugees coming to the tide country were premised on a false assumption-they chose this place because they thought that the new Left government in West Bengal would sympathize with their cause. Actually, the government falling short of the expectation of the refugees-not being able to meet their needs or not being sympathetic to their problems-was not a new story in West Bengal. But what happened in 1979, the way they were forcible evicted from the island, was a gross betrayal by the Left government. There was a symbiotic relationship between the refugee movement and Left politics in West Bengal in the early years of independence. The refugees at Morichjhapi showed initiative and organization in their attempt to build a new life. Nirmal, the protagonist of the novel, writes of the refugee initiatives in his diary:

His conscious engagement with the natural world draws our attention to impending calamity of the global environment. The eco-critical investigation figures out that the novel "The Hungry Tide" penetrates a picture of man's complex interaction with nature. The Sunderbans in the Bay of Bengal are some islands where people share with animals. The condition of their living is much inferior to animals. The predicament the inhabitants suffer due to unwanted, unexpected tidal surges and tiger attack shows a serious ecological calamity on earth.

The contention that Ghosh, as an anthropologist turned writer, shows an engagement with the environmental decline in the Sunderbans might create an awareness to help prepare action plans for the safety of the settlers. In an interview for Brisbane Festival, Australia, 2004, Amitav Ghosh himself said that he was more interested in characters than issues when he went to write a story. This is exactly true what he maintained in the interview. "The Hungry Tide" is not only a tale of settlers and their physical surroundings in the
Sunderbans but also an exploration into the hearts of the characters. This fact that the present study detects mental agony of the inhabitants living in a fragile ecosystem is information about the condition of the people; and the present generation can take up fruitful steps to help improve the Tide country situation.

Amitav Ghosh is a writer of postmodern fiction. His stories travel throughout time and space, creating an account that has an asymmetrical flow. In "The Hungry Tide", he shuttles between the Morichjhanpi incident from Nirmal's point of view, and the present day travels of Piya Roy, Kanai and Fokir. This time-travel is vital to the story and created an intricacy of sub-topics and plots. Another trait of Ghosh that is continued in "The Hungry Tide" is the scrupulous research that allows a mixture of fiction and fact to the extent that they stand undifferentiated. Touching upon various topics from refugees, freedom and war, to life in the Sundarbans, the absence of language in communication, development, women trafficking and much more, he takes the reader through a whirlwind of events and emotions. He includes the myths of the people who are living in the Sundarbans to explain the nature of living in a country whose shape is determined by tide and weather. The myths are often presented like songs or with rhymes. This style creates different languages for nature, myth and people.

\section{REFERENCES}

Aldama and Frederic Luis, 2002. An Interview with Amitav Ghosh, World Literature Today.

Bhatt, Indira and Indira Nityanandan, 2003. The fiction of Amitav Ghosh, New Delhi, Creative.

Dhawan, R.K. 1999. The Novels of Amitav Ghosh, Prestige Books, New Delhi.

Garrard, Greg, 2004. Ecocriticism. New York: Routledge.

Ghosh, Amitav. 2004. The Hungry Tide, London, Harper Collins.

Glotfelty, Cheryll and Harold Fromm, 1996. The Ecocriticism Reader: Landmarks in Literary Ecology. Athens and London: University of Georgia.

Gopal, Priyamvada, 2010. The Indian English Novel, New York, Oxford University Press. 